\title{
Potensi akumulasi Aurum (Au) pada beberapa jenis tumbuhan di wilayah penambangan emas Kapuas Tengah
}

\author{
S. Sunariyati ${ }^{*}$, M. Amin², L. Hakim ${ }^{3}$ \\ 1Program Studi Biologi, FMIPA, Universitas Palangka Raya, Indonesia \\ 2Program Studi Biologi, FMIPA, Universitas Negeri Malang, Indonesia \\ 3Jurusan Biologi, FMIPA, Universitas Brawijaya, Indonesia
}

\begin{abstract}
Abstrak.
Terdapatnya logam Au dalam tumbuhan masih menjadi permasalahan yang belum terpecahkan dan perlu diteliti. Tujuan penelitian ini adalah (1) menginventarisasi dan mengidentifikasi beberapa jenis tumbuhan yang dimanfaatkan masyarakat sebagai indikator terdapatnya emas. (2) menganalisis kandungan $\mathrm{Au}$ pada spesimen tumbuhan yang diyakini sebagai penunjuk terdapatnya emas di wilayah penambangan. Kegiatan penelitian ini terdiri dari dua tahap. Tahap I adalah identifikasi jenisjenis tumbuhan di wilayah penambangan emas yang diyakini penduduk setempat sebagai indikator keberadaan emas. Tahap II pembuktian ilmiah yang dilakukan melalui analisis kandungan Aurum (Au) dengan menggunakan Atomic Absorption Spectroscopy (AAS), yang diamati pada panjang gelombang 242,8 nm. Hasil inventarisasi dan identifikasi diperoleh 11 jenis tumbuhan yang diyakini oleh penambang emas sebagai tumbuhan indikator terdapatnya emas. Hasil analisis laboratorium menunjukkan pada 11 jenis tumbuhan dapat mengakumulasi Au di dalam jaringan akar, batang dan daunnya dengan kadar yang bervariasi. Kadar rata-rata tertinggi terdapat di batang sebesar $(130,90 \mathrm{ppb})$, di daun (84 ppb) dan terendah di akar dengan rata-rata $(67,81$ ppb). Adanya akumulasi Au pada tumbuhan berkorelasi dengan terdapatnya Au di dalam tanah.
\end{abstract}

Abstract.

The presence of Au in plants is still an unsolved problem and needs to be investigated. The purposes of this research were to (1) inventory and identify several species of plants that are utilized as an indicator of gold. (2) to analyze the content of $A u$ on the specimens of plants that are believed as indicator of the existence of gold in the gold mining region. The activities of this research consisted of two stages. Phase I was the identification of the species of plants in the gold mining region believed by the local society as an indicator of the presence of gold. Phase II scientific proof was done through the analysis of the content of Au using AAS, was observed at a wavelength of $242.8 \mathrm{~nm}$. The results of the inventory and identification obtained 11 plants species, believed by miners as indicator of gold. The results of the laboratory analysis showed 11 plants species could accumulate Au on the root, stem and leaves with a varied levels. The highest average levels found in the stems (135.81 ppb), in the leaves (88.81 $p p b)$ and the lowest at the roots with an average of 67.81 $\mathrm{ppb}$. The existence of an accumulation of $\mathrm{Au}$ in plants correlates with there Au in the ground.

Keywords: accumulation of Au, gold mining

Kata kunci: akumulasi $\mathrm{Au}$, penambangan emas

\section{PENDAHULUAN}

Indonesia memiliki hutan tropis dengan sumber kekayaan flora yang besar dan struktur vegetasi yang kompleks. Beranekaragam jenis tumbuhan yang ada di hutan selain dimanfaatkan sebagai tumbuhan obat, ada juga yang berpotensi secara praktis sebagai indikator lingkungan tertentu. Berkaitan dengan kekayaan keanekaragaman hayati Indonesia, maka pemanfaatan tumbuhan berkembang dalam segala maksud dan keperluan, terutama yang berkenaan dengan makna budaya, jadi bukan hanya nilai ekonominya saja. Perilaku tradisional yang selama ini sudah mengakar dalam kehidupan budaya

\footnotetext{
${ }^{*}$ Korespondensi Penulis

Email : sunariyati1516@yahoo.com
} 
masyarakat perlu dimanfaatkan untuk pelestarian kearifan lokal di wilayah setempat.

Potensi endapan emas terdapat hampir di setiap wilayah Indonesia. Di daerah Kapuas Tengah, Kalimantan Tengah memiliki hutan yang sangat luas dan terdapat beranekaragam jenis tumbuhan yang dimanfaatkan oleh penduduk setempat (indigenous knowledge). Untuk mengetahui tempat-tempat tertentu yang diperkirakan mengandung emas, sebagian penduduk berdasar informasi dan hasil wawancara dengan penambang emas, ada yang menggunakan jenis tumbuhan tertentu sebagai penanda (indikator) untuk menunjukkan tempat terdapatnya emas. Ada beberapa jenis tumbuhan hutan yang diyakini oleh masyarakat suku Dayak di wilayah Kapuas Tengah, Kalimantan Tengah sebagai tumbuhan penanda (indikator) adanya logam emas ( $\mathrm{Au}$ ). Namun hingga saat ini belum diketahui kebenarannya secara ilmiah, mengapa tumbuhan tersebut digunakan sebagai penanda.

Berdasarkan hasil penelitian Girling dan Peterson (1980) dilaporkan bahwa beberapa jenis tumbuhan dapat mengakumulasi logam emas di dalam jaringan tubuhnya. Elemen ini dapat ada dalam tumbuhan dalam konsentrasi yang bervariasi, tergantung jenis, tingkat pertumbuhan, dan faktor tanah di lingkungan sekitar. Hasil eksperimen secara statistik, ada korelasi antara faktor tanah dengan keberadaan tumbuhan dimana tumbuh secara alami yang digunakan untuk mendeteksi kekayaan mineral di dalam tanah. Girling dan Peterson (1980) menunjukkan bahwa konsentrasi logam emas di dalam tumbuhan yang diambil dari daerah yang berbeda, kandungannya sangat kecil (dalam ppb) yaitu antara 10 - 200 ppb (berat kering). Selanjutnya hasil pengamatan menunjukkan adanya logam emas di bagian akar dan batang pada tujuh spesies tumbuhan yang diteliti.

Kondisi lingkungan sangat menentukan ketersediaan unsur hara bagi tumbuhan. Ulrich dalam Sutedjo (1989) menyatakan bahwa apa yang terdapat dalam tubuh tumbuhan sangat berhubungan dengan pertumbuhannya pada tanah dengan kadar hara yang dikandungnya. Sesuai dengan hasil penelitian Supriyono dan Prehaten (2014) bahwa kondisi unsur hara dalam tanah memiliki kadar unsur hara yang selaras dengan kadar di daun. Keberadaan suatu unsur di dalam tubuh tumbuhan memang sangat dimungkinkan termasuk logam emas (Aurum), karena pada dasarnya semua unsur ada di dalam tubuh tumbuhan walaupun jumlahnya sangat kecil (Gupta \& Sarivasta 1996).

Cara transportasi logam emas pada tumbuhan sebagian tergantung pada proses metabolisme dalam larutan nutrisi yang mengandung emas dan pengaruh pH media pertumbuhan. Lokasi penyimpanan logam emas distribusinya tidak sama, ada beberapa spesies mengakumulasi di bagian tunas khusus (H. vulgare dan P. tanaceti), tetapi dari hasil percobaan sebagian besar dalam bentuk 
terlarut terdapat di bagian akar dan di batang dalam bentuk tidak terlarut. Distribusi logam Aurum dalam bentuk terlarut dengan sianida banyak terdapat di akar dan batang, tetapi di akar banyak dalam bentuk terikat dengan klorida yang tidak terlarut. Hal ini menunjukkan bahwa komponen emas yang dialirkan ke batang tidak disimpan dalam bentuk tidak terlarut (Girling dan Peterson 1980).

Berdasar pemikiran adanya kemampuan tumbuhan dalam menyerap ionion dengan mekanisme pengangkutan tertentu yang berakibat adanya akumulasi mineral logam Au di dalam tubuh tumbuhan, maka sebagai implikasi ekologisnya perlu dibuktikan apakah pada tumbuhan yang diduga sebagai penanda/indikator adanya Au juga memiliki potensi untuk menyerap dan mengakumulasi logam $\mathrm{Au}$. Hal ini tentunya perlu dikaji lebih lanjut dalam suatu penelitian.

\section{METODE}

\subsection{Lokasi Kajian dan Waktu Penelitian}

Lokasi penelitian di kawasan hutan wilayah penambangan emas di Desa Masaran dan Desa Pujon, Kecamatan Kapuas Tengah, Kabupaten Kapuas, Provinsi Kalimantan Tengah. Secara geografis Kecamatan Kapuas Tengah terletak pada koordinat antara $114^{\circ} \mathrm{BT}-114^{\circ} 2^{\prime} 0^{\prime \prime}$ BT dan $0^{\circ} 48^{\prime} 0^{\prime \prime} \mathrm{LS}$ $1^{\circ} 27^{\prime} 62^{\prime \prime}$ LS. Penelitian ini dilaksanakan pada Mei 2011 sampai Juni 2012. Peta lokasi penelitian terlihat pada Gambar 1.

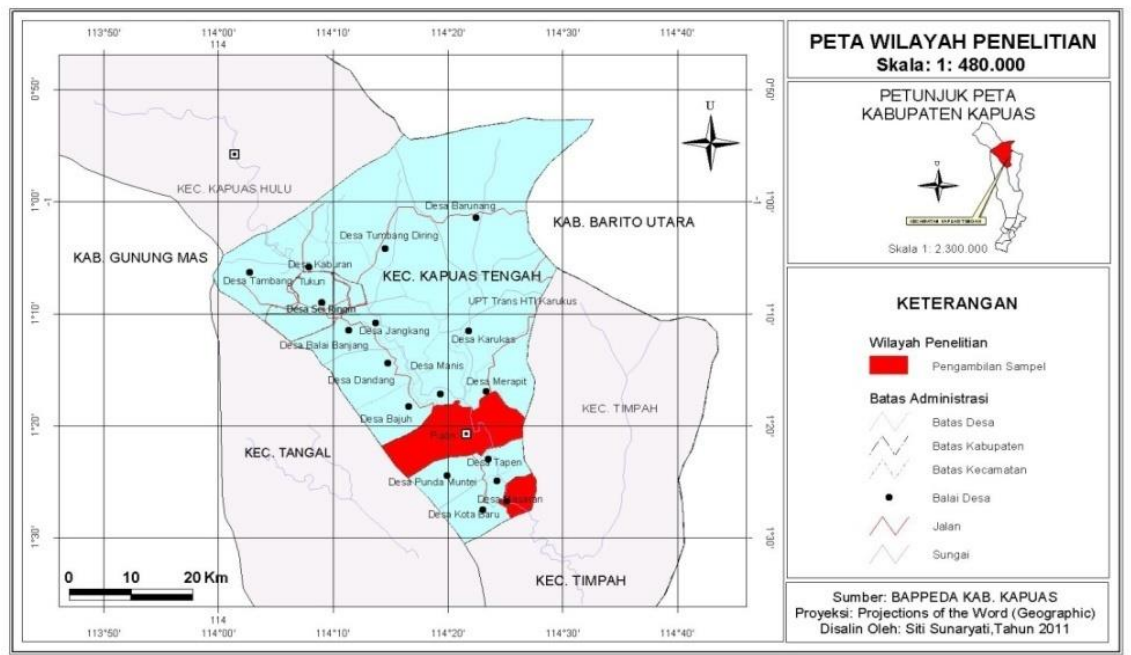

Gambar 1. Peta lokasi penelitian.

Penelitian tahap I menginventarisasi dan identifikasi pengetahuan lokal masyarakat suku Dayak Ngaju tentang tumbuhan yang dimanfaatkan sebagai 
penanda terdapatnya emas. Untuk mempelajari pengetahuan lokal masyarakat tentang tumbuhan digunakan pendekatan kualitatif. Pendekatan kualitatif digunakan untuk menggali informasi dan mendiskripsikan pengetahuan lokal tentang pemanfaatan tumbuhan di wilayah penambangan emas Kapuas Tengah.

Tahap kedua terdiri dari dua kegiatan, yaitu identifikasi spesimen dan analisis kadar Au pada tanah dan tumbuhan. Untuk identifikasi tumbuhan yang ditemukan di lokasi penambangan emas digunakan pendekatan diskriptif kualitatif, yaitu dengan cara mendiskripsikan spesimen tumbuhan dan dicocokkan dengan buku/leteratur atau dokumen lain yang ada. Selanjutnya dilakukan analisis kadar Au pada tanah dan tumbuhan secara kuantitatif.

\subsection{Prosedur Analisis Data}

Analisis kadar Au digunakan pendekatan kuantitatif, yang bertujuan untuk mengukur kadar $\mathrm{Au}$ pada tumbuhan dan dibandingkan dengan tumbuhan sejenis yang tumbuh di tempat yang berbeda. Analisis kandungan Aurum ( $\mathrm{Au}$ ) dengan menggunakan Atomic Absorption Spectroscopy (AAS) yang diamati pada panjang gelombang 242,8 $\mathrm{nm}$, dengan mengikuti prosedur analisis yang diadaptasi dari Vogel's (2000). Data kadar Au pada tumbuhan dari setiap desa yang diamati, selanjutnya dianalisis dengan menggunakan uji korelasi, yaitu untuk melihat hubungan antara kadar Au tanah dengan akar, batang dan daun tumbuhan. Analisis yang digunakan adalah analisis korelasi Pearson Product Moment (PPM) yang dibantu Statistical Product and Service Solution (SPSS) for Windows versi 17.

\section{HASIL DAN PEMBAHASAN \\ 3.1. Hasil Hasil Analisis Kadar Au pada Beberapa Jenis Tumbuhan Penanda}

Berdasarkan informasi dari 40 informan yang terdiri dari para penambang emas, pemangku adat/damang, dan kepala desa, diperoleh 11 jenis tumbuhan yang diinformasikan dapat mencirikan kandungan emas dalam tanah, dengan hasil yang berbeda-beda. Hal ini dapat dibuktikan dari hasil analisis kadar $\mathrm{Au}$ pada tumbuhan menunjukkan beberapa jenis tumbuhan memiliki kemampuan menyerap logam $\mathrm{Au}$, tetapi dalam kadar yang bervariasi. Tumbuhan memiliki sifat toleran terhadap lingkungan dan mampu mengakumulasi logam pada jaringan akar, batang dan daunnya. Perbedaan kadar Au pada akar, batang dan daun tumbuhan yang dimanfaatkan sebagai indikator dapat dilihat pada (Gambar 2). Kadar $\mathrm{Au}$ pada masing-masing jenis tumbuhan penanda dan reratanya ditunjukkan pada (Tabel 1). 


\begin{tabular}{|l|l|l|l|}
\multicolumn{5}{c}{ Kadar Au pada Tanah danTumbuhan } \\
\hline
\end{tabular}

Gambar 2. Perbandingan kadar Au pada tanah, akar, batang dan daun.

Tabel 1. Kadar Au pada masing-masing jenis tumbuhan penanda.

\begin{tabular}{lllcccc}
\hline No & Nama Lokal & \multicolumn{2}{c}{ Nama Ilmiah } & \multicolumn{4}{c}{ Kadar Au (ppb) } \\
\hline & & & Akar & Bang & Daun & Tanah \\
\hline 1 & Kapur naga & Calophyllum hosei Ridl & 89 & 228 & 149 & 637 \\
2 & Katumbu & Dillenia excelsa Gilg & 67 & 115 & 60 & 487 \\
3 & Karuing & Dipterocarpus crinitus Dyer & 82 & 143 & 89 & 432 \\
4 & Katune & Agrostistachys sessilifolia & 70 & 104 & 80 & 585 \\
& & (Kurz) Pax\&Hoffm & & & & \\
5 & Pelawan & Tristania obovata R.Br. & 40 & 80 & 54 & 374 \\
6 & Galam tikus & Tristaniopsis merguensis Griff & 68 & 120 & 74 & 464 \\
7 & Katiau & Ganua motleyana (de Vriese) & 78 & 212 & 135 & 517 \\
& & Pierre ex Dubard & & & & \\
8 & Rangas & Swintonia glauca Engl. & 51 & 95 & 67 & 476
\end{tabular}




\begin{tabular}{clllllc}
\hline No & Nama Lokal & \multicolumn{1}{c}{ Nama Ilmiah } & \multicolumn{3}{c}{ Kadar Au (ppb) } \\
\hline 9 & Kayu lalas & Syzygium zeylanicum (L) DC & 72 & 125 & 97 & 381 \\
10 & Tumih & $\begin{array}{l}\text { Combretocarpus rotundatus } \\
\text { Miq }\end{array}$ & 47 & 75 & 30 & 407 \\
& \multirow{2}{*}{ Kayu emas } & $\begin{array}{l}\text { Memecylon myrsinoides Blume } \\
\text { Rerata }\end{array}$ & 82 & 143 & 89 & 562 \\
\hline
\end{tabular}

\subsection{Potensi Akumulasi Au pada Tumbuhan}

Berdasarkan hasil wawancara mendalam dengan informan dinyatakan bahwa keyakinan tentang tumbuhan penanda/indikator yang digunakan sebagai penanda terdapatnya logam emas, ada hubungannya dengan kondisi tanahnya. Untuk membuktikan pernyataan tersebut, dianalisis kadar $\mathrm{Au}$ tanah sebagai media tempat pertumbuhannya. Data hasil analisis kadar Au (Gambar 2) menunjukkan bahwa adanya akumulasi Au pada tumbuhan yang terdapat di bagian akar, batang dan daun. Rerata akumulasi kadar Au tertinggi terdapat di bagian batang sebesar 135,81 ppb, kedua di daun sebesar 88,81 ppb dan terendah di akar sebesar 67,81 ppb. Di tempat-tempat yang ditumbuhi tumbuhan tersebut, dari hasil analisis media tumbuhnya (tanah) menunjukkan adanya kadar Au yang tinggi di dalam tanah sebesar 483,81 ppb. Terutama untuk tanah sebagai tempat tumbuh katune, dinyatakan informan sebagai tanda spesifik sebagai tumbuhan indikator, memiliki kadar $\mathrm{Au}$ tanah lebih tinggi dibandingkan tumbuhan lain.

Tumbuhan berpotensi mengambil $\mathrm{Au}$ dari lingkungan dan mengakumulasikan di dalam jaringan tubuhnya, hal ini karena beberapa jenis tumbuhan dari beberapa famili terbukti memiliki sifat hipertoleran, yaitu mampu mengakumulasi logam dengan konsentrasi tinggi pada jaringan akar, batang dan daunnya, sehingga bersifat hiperakumulator. Dikemukakan Gupta \& Sarivasta (1996) keberadaan suatu unsur di dalam tubuh tumbuhan memang sangat dimungkinkan termasuk logam emas $(\mathrm{Au})$, karena pada dasarnya semua unsur ada di dalam tumbuhan walaupun jumlahnya sangat kecil. Akumulasi Au pada jaringan tumbuhan (berkayu) pada berberapa jenis tumbuhan telah dilaporkan oleh Jones dalam Girling (1980) biasanya dalam kisaran ppb/berat kering. Ini sejalan dengan hasil penelitian, dari beberapa sampel yang dianalisis ternyata akumulasi Au di akar, batang dan daun juga dalam kisaran ppb.

Hasil analisis kadar Au menunjukkan bahwa kadar Au tumbuhan tertinggi pada bagian batang. Akumulasi pada batang yang lebih tinggi dibanding bagian lain, kemungkinan karena senyawa emas dalam bentuk terlarut pada saat diangkut dari akar menuju ke batang selanjutnya di batang tidak disimpan dalam bentuk terlarut. Hal ini terjadi karena mekanisme pengangkutan logam yang bersifat Cellular exclusion (penyimpanan dalam sel) di ruang bebas apoplastic yang membentuk kompleks diantara membran dan dinding sel. Hal 
ini sesuai dengan hasil penelitian Dunn (2007) dari 24 sampel Alnus crispa yang diabukan, berdasarkan hasil analisis kimia diperoleh konsentrasi yang bervariasi yaitu berkisar 5 - 14 ppb pada bagian ranting, 14 ppb di daun, dan 140 ppb di bagian batang (kulit kayu). Kesimpulan yang dapat diambil dari data hasil analisis abu adalah bahwa sejumlah kecil Au dapat dipertahankan dalam sel-sel ranting atau daun (Alnus crispa) dan sebagian terlarut dalam getah. Menurut Padmavathiamma dan Li (2007) beberapa tumbuhan hiperakumulator dapat menyerap senyawa dalam jumlah besar dibandingkan dengan tumbuhan lain. Hiperakumulator logam pada tumbuhan dapat menumpuk dan konsentrasinya lebih besar di bagian batang dibanding pada tumbuhan non-akumulator yang biasanya ditemukan.

Data kadar Au menunjukkan, kadar Au tumbuhan tertinggi terdapat pada batang, kemudian daun dan kadar terendah terdapat di akar. Hasil analisis korelasi antara akar, batang dan daun dengan tanah menunjukkan, adanya korelasi positif antara kadar Au tanah dengan kadar Au pada tumbuhan, hal ini berarti adanya akumulasi Au pada tumbuhan juga menunjukkan terdapatnya $\mathrm{Au}$ pada tanah. Hasil analisis korelasi menunjukkan adanya korelasi yang signifikan antara akar, batang, daun dengan tanah. Walaupun kadar Au di akar paling rendah, tetapi menunjukkan hasil korelasi yang signifikan.

\subsection{Mekanisme Transport Au pada Tumbuhan}

Serapan dan transportasi Au di zona perakaran transportasinya melawan gravitasi dari akar ke daun, dan akumulasi terjadi di daun, kulit kayu, ranting dan akhirnya ke sampah/seresah. Tumbuhan dapat menjadi kontributor penting bagi mediasi biologis siklus Au di tanah regolith (Reith et al. 2007). Tumbuhan mengambil beberapa jenis logam dari lingkungannya, dipengaruhi kondisi tanah seperti $\mathrm{pH}$, suhu dan oksigen merupakan faktor penting dalam pengangkutan unsur-unsur anorganik maupun senyawa organik. Selain itu beberapa senyawa organik memainkan peran dalam pengangkutan logam membentuk kompleks dengan senyawa di dalam tanah dan meningkatkan bioavialability dan serapan logam (Babula et al. 2008). Melalui transporter berupa molekul yang memiliki massa rendah secara aktif disekresikan oleh akar tumbuhan dan berfungsi sebagai kelators. Mekanisme pengkelatan, diperkirakan unsur logam diserap dalam bentuk kompleks logam-kelat yaitu Phytochelatin sulfhydryl yang disintesis dari glutathion dalam tumbuhan (Narasimha \& Prasad 1999)

Secara fisiologis mekanisme transport Au belum banyak diteliti, namun pada dasarnya cara pengangkutan Au sama dengan logam lain. Tumbuhan mengakumulasi logam dari larutan tanah. Sebelum logam di transportasi dari larutan tanah ke dalam tumbuhan, harus melewati permukaan akar melalui mekanisme pengangkutan pasif. Ion logam bergerak melalui pori dinding sel 
akar melalui arus massa, atau melalui proses pengangkutan symplastis melalui sel-sel akar. Penyerapan Au dari larutan tanah ke permukaan akar kemungkinan dalam bentuk ion yang teroksidasi $\left(\mathrm{Au}^{+}+\right.$e) dan masuk ke dalam sel akar. Sifat kompleks dari rizosfer yang dinamis dan terus-menerus berubah menyebabkan terjadinya variasi dalam pengambilan logam. Proses selanjutnya dikemukakan Prasad (2006) bahwa ada protein membran yang khusus pada tumbuhan dapat mengenali struktur kimia logam esensial, protein ini mengikat logam dan kemudian siap untuk penyerapan dan transportasi. Pada akar elemen ini diangkut melalui sistem vaskular ke bagian atas (tunas). Chelator yang berbeda dapat terlibat dalam translokasi kation logam melalui xilem, seperti asam organik (malat, sitrat, histidin). Selanjutnya logam diangkut dalam bentuk kompleks khelat dan ditranslokasi ke atas melalui xilem.

\subsection{Hubungan Akumulasi Au dengan Potensi terdapatnya Emas}

Adanya Au pada beberapa jenis tumbuhan yang diyakini sebagai tumbuhan indikator terdapatnya emas, membuktikan bahwa pengetahuan lokal masyarakat tentang tumbuhan penanda bisa dibuktikan secara ilmiah. Hal ini sejalan dengan yang dikemukakan Dunn(2007) yang melakukan eksplorasi di Indonesia, di wilayah Papua New Guinea, di area tertentu ditemukan pohon yang memiliki bentuk tulang daun yang khas, diantaranya Astronidium paluense yang digunakan untuk menduga adanya mineralisasi Au. Hal ini juga mengindikasikan bahwa adanya kandungan logam pada tumbuhan diyakini merupakan alat untuk menduga kandungan deposit di dalamnya. Analisis kandungan Au pada tumbuhan merupakan salah satu cara yang efektif untuk menduga keberadaan logam berat yang ada di dalam tanah.

Tumbuhan pada dasarnya dapat mengakumulasi $\mathrm{Au}$, namun penulis tidak merekomendasikan hasil penelitian ini untuk proses ekstraksi emas (Phytomining), karena pemanenan emas lewat tumbuhan dinilai tidak ekonomis dan merusak lingkungan, disamping itu diperlukan biaya yang besar. Walaupun akhir-akhir ini dicari beberapa jenis tumbuhan hiperakumulator emas untuk kepentingan ekonomis. Kemampuan tumbuhan dalam mengakumulasi emas dimanfaatkan untuk Phytomining yaitu penggunaan tumbuhan untuk mengakumulasi logam berharga dari sampah pertambangan substrat (tailing) atau tanah mineral. Teknik ini diterapkan di daerah dimana konsentrasi logam tidak cocok untuk diekstraksi dengan cara teknologi konvensional (Anderson et al. 1999; Bali et al. 2010; Corral et al. 2010).

\section{KESIMPULAN DAN SARAN}

Hasil inventarisasi dan identifikasi pada tumbuhan yang diyakini oleh masyarakat suku Dayak Ngaju sebagai tumbuhan indikator terdapatnya emas di 
wilayah penambangan emas Kecamatan Kapuas Tengah, diperoleh 11 jenis tumbuhan dengan habitat yang spesifik. Hasil analisis laboratorium pada 11 jenis tumbuhan yang ditemukan, dapat mengakumulasi $\mathrm{Au}$ di dalam jaringan akar, batang dan daunnya dengan kadar yang bervariasi. Kadar rata-rata tertinggi terdapat pada batang sebesar $130,90 \mathrm{ppb}$, pada daun $84 \mathrm{ppb}$ dan terendah pada akar dengan rata-rata $67,81 \mathrm{ppb}$.

Tumbuhan mampu mengambil dan mengangkut $\mathrm{Au}$ dari dalam tanah melalui akar yang terakumulasi di batang dan daun. Logam Au diangkut dalam bentuk kompleks khelat dan ditranslokasi ke atas melalui xilem. Hasil analisis korelasi menunjukkan adanya korelasi yang signifikan antara kadar Au di akar, batang dan daun dengan kadar Au tanah. Hal ini berarti terdapatnya Au pada tumbuhan berpotensi terdapatnya Au dalam tanah.

Banyak jenis tumbuhan di wilayah Kalimantan Tengah yang belum diketahui manfaatnya, oleh sebab itu disarankan untuk dilakukan penelitian eksplorasi jenis-jenis tumbuhan bermanfaat di wilayah yang berbeda. Hasil penelitian tentang terdapatnya logam Au pada tumbuhan merupakan aspek yang menarik untuk dilakukan penelitian lebih lanjut, karena masih banyak aspek yang belum diketahui dengan pasti tentang pemanfaatan dan mekanisme transportasi Au pada tumbuhan. Salah satu upaya konservasi yaitu dengan cara mempertahankan keberadaan tumbuhan pada habitatnya agar tidak ditebang untk kepentingan penambangan.

\section{Daftar Pustaka}

Anderson CWN, Brooks RR and Stewart RB. 1999. Gold uptake by Plants. Soil and Earth Science Institute of Natural Resource. Massey University. Palmerston North, New Zealand. Gold Bulletin June 32(2):48-52.

Babula P, Adam V, Opatrilova R, Zehnalek HL and Kizek R. 2008. Uncommon heavy metals, metalloids and their plant toxicity:a review. Environ Chem Lett 6:189-213.

Bali R, Siegele R and Harris AT. 2010. Phytoextraction of Au: uptake, accumulation and cellular distribution in Medicago sativa and Brassica juncea. Chemical Enginering Journal 156:286-297.

Corral VW, Lopez MR, Perez JL, Vargas MA and Anderson C. 2010. Gold phytomining in arid and semiarid soils. Brisbane, Australia. Soil Solutions for a Changing World 1-6.

Dunn CE. 2007. New perspective on biogeochemical exploration [internet]. Tersedia di: https://www.researchgate.net/publication/267256996.

Girling CA dan Peterson PJ. 1980. Gold in Plant. Gold Bulletin 13 [internet]. Tersedia di: http://www.goldbulletin.org. 
Girling CA, Peterson PJ and Warren. 1979. Plants as indikators of gold mineralization at Watson Bar, British, Colombia. Canada. Economic Geology 74(4):902-907.

Gupta UC and Sarivasta PC. 1996. Trace elements in crop production. India Science Publisher. Inc. New Delhi.

Narasimha M and Prasad V. 1999. Feasible biotechnological and bioremediation strategies for serpentine soils and mine spoils. Electron. J. Biotechnol 2(1).

Padmavathiamma PK and Li LY. 2007. Phytoremediation technology: hyperaccumulation metals in plants. Springer Science Business Media B.V. 2007.

Reith F, Lengke MF, Falconer D, Craw D and Southam G. 2007. The geomicrobiology of gold. Australia. The University of The ISME Journal 2007(1):567-584.

Supriyono H dan Prehaten D. 2014. Kandungan unsur hara dalam daun jati yang baru jatuh pada tapak yang berbeda. Jurnal Ilmu Kehutanan 8(2).

Vogel's AI. 2000. Textbook of quantitative chemical analysis 6th ed. Prentice Hall. London. 